AL-IQTISHOD: Jurnal Pemikiran dan Penelitian Ekonomi Islam

E-ISSN: 2745-85I2 P-ISSN: 2407-6600

Volume 9 Issue 2 Juli 202I | Page: 19-38

DOI: $\operatorname{xxxxxxxxxxxxxxxx}$

\title{
Bank Mini Syariah di Pesantren Nurul Jadid Paiton Probolinggo (Peluang \& Harapan)
}

\author{
Muhammad Zainuddin Sunarto \\ Universitas Nurul Jadid Paiton Probolinggo \\ zain2406@gmail.com \\ Winda Aulia, Nabila \\ Universitas Nurul Jadid Paiton Probolinggo \\ auliawinda43@gmail.com, nabilabela625@gmail.com
}

\begin{abstract}
The order of the Indonesian Muslim community was built because of the relationship between economy, education and politics. This is because the joint culture or tradition of a nation is basically built through the economic process-capital accumulation, education-knowledge accumulation and ruling politics-accumulation of power. On the other hand, economic development in Indonesia is growing, as evidenced by the establishment of many Islamic financial institutions that have become the foundation of economic life in Indonesia, although in practice they are still found in urban areas. Educational institutions, especially Islamic boarding schools, can take a role in this economic development, by establishing internal financial institutions, in this context by establishing Sharia Mini Banks, in collaboration with existing Islamic banks. The existence of the Nurul Jadid Islamic Boarding School cannot be separated from the social construction which describes a transcendence of the journey of social historicity. What becomes an important point is the fact of the existence of pesantren as one of the triggers for social cohesion. This necessity is because the pesantren is open with the spirit of simplicity, kinship and social care. The Nurul Jadid Islamic Boarding School has the opportunity to establish a Sharia Mini Bank as an economic service for the pesantren community as well as a laboratory for various departments related to finance, besides that the pesantren has the strength of the financial assets of the pesantren community who will later become customets.
\end{abstract}

Keywords: Sharia Mini Bank, SWOT Analysis, Nurul Jadid Islamic Boarding School

Abstrak: Tatanan masyarakat Muslim Nusantara terbangun karena adanya hubungan antara ekonomi, pendidikan, dan politik. Karena, sendi sendi kebudayaan atau tradisi suatu bangsa pada dasarnya dibangun melalui proses ekonomi-akumulasi modal, pendidikan-akumulasi pengetahuan dan politik-akumulasi kekuasaan yang berkuasa. Sisi lain, perkembangan ekonomi di Indonesia semakin berkembang, dengan dibuktikan banyak berdirinya lembaga keuangan syariah yang sudah menjadi sendi kehidupan ekonomi di Indonesia, meskipun pada prakteknya masih terdapat pada wilayah kota saja. Lembaga pendidikan, khususnya pesantren bisa mengambil peran untuk perkembangan ekonomi tersebut, dengan mendirikan lembaga keuangan di internal sendiri, dalam konteks ini dengan mendirikan Bank Mini Syariah, melalui kerjasama dengan perbankan syariah yang telah ada. Keberadaan Pesantren Nurul Jadid tak lepas dari konstruksi kemasyarakatan yang 
mencitakan suatu transendensi atas perjalanan historisitas sosial. Hal yang menjadi titik penting adalah kenyataan eksistensi pesantren sebagai salah satu pemicu terwujudnya kohesi sosial. Keniscayaan ini karena pesantren hadir terbuka dengan semangat kesederhanaan, kekeluargaan dan kepedulian sosial. Pesantren Nurul Jadid sangat berpeluang untuk mendirikan Bank Mini Syariah sebagai layanan ekonomi masyarakat pesantren serta menjadi laboratorium bagi berbagai jurusan yang berhubungan dengan keuangan, selain itu pesantren memiliki kekuatan aset keuangan dari masyarakat pesantren yang dikemudian hari menjadi nasabah.

Kata Kunci: Bank Mini Syariah, Analisis SWOT, Pesantren Nurul Jadid 
Muh Zainuddin S., dkk.

\section{A. Pendahuluan}

Islam pada posisinya, tidak hanya sebagai agama namun harus juga menjadi pegangan hidup dari seluruh aspeknya, islam harus mengatur seluruh sendiri kehidupan manusia secara universal. Seluruh sisi kehidupan manusia tidak lepas dari perhatian agama, sehingga adanya kepastian terhadap pelaksanaannya bisa sangat jelas. Topik pembahasan pada agama Islam tersebut sangat bervariasi, mulai keyakinan, keimanan, fiqh ibadah, fiqh muamalah, fiqh siyasah, politik, ekonomi. Hal itu merupakan beberapa bagian saja,yang menunjukkan bahwa Islam sangat universal dalam menjawab berbagai permasalahan.

Universalitas Islam dalam berbagai sisi diatas tersebut diatas, tidak hanya pada satu tendesi saja, namun juga menyeluruh terhadap berbagai hal, sehingga bisa berkesinambungan dalam prakteknya kehidupan masyarakat. Hasil dari proses tersebut akan membentuk umat yang unggul dan akan memiliki peradaban yang baik dari berbagai sisi melalui isi universalitas Islam tersebut. Dalam pembentukan ummat tersebut, pesantren bisa mengambil posisi untuk mencapai tujuan tersebut, karena notabene mayoritas penduduk di Indonesia merupakan pemeluk agama Islam.

Sejarah perkembangan pesantren di Indonesia, tidak bisa lepas dari sejarah Indonesia itu sendiri. Pesantren telah meunjukkan eksistensinya dalam pembangunan nasional tidak hanya pada bidang pendidikan saja, namun juga dalam pengenmbangan ekonomi, politik, hukum, dan lainnya. Khusus pada pengembangan ekonomi, pesantren telah memulai hak tersebut dengan selalu berdampingan dengan masyarakat kelas bawah, baik petani maupun nelayan. ${ }^{1}$

Hubungan antara ekonomi, pendidikan dan politik inilah yang menciptakan tradisi dan tatanan masyarakat Muslim Nusantara. Karena, sendi sendi kebudayaan atau tradisi suatu bangsa dan komunitas pada dasarnya dibangun melalui proses ekonomi-akumulasi modal, pendidikan-akumulasi pengetahuan dan politik akumulasi kekuasaan yang berjalan

\footnotetext{
I Tirta Rahayu Ningsih, 'Pemberdayaan Ekonomi Pesantren Melalui Pengembangan Sumber Daya Lokal', Lembaran Masyarakat: Jurnal Pengembangan Masyarakat Islam, 3.I (2017), 57-78.
}

Volume. 9/No. 2/Juli 202I Al-Iqtishod | 19 
Bank Mini Syariah di Pesantren ...

bersamaan. Semakin baik status ekonomi, mutu pendidikan, serta semakin luas pengaruh kekuasannya, maka semakin erudite kebudayaan dan tradisi yang dilahirkan dan dikembangkan. Termasuk pesantren. Yang tidak mungkin akan mengalami kemajuan jika tidak adanya perbaikan dari segi ekonomi. Karena, ekonomi bagi suatu lembaga seperti pondok pesantren merupakan jantung kehidupan bagi kemajuan baik dari system pendidikan maupun bidang lainnya. ${ }^{2}$

Belakangan ini perkembangan lembaga keuangan bank dan lembaga non bank mengalami peningkatan yang sangat pesat, tentu perkembangan ini sangat memerlukan dukungan khususnya perbankan syariah perlu didukung supaya perkembangan bank syariah di Indonesia menjadi perbankan syariah trendsetter keuangan syariah Asia.

Kebijakan pemerintah terhadap perbankan syariah di Indonesia telah diatur dalam Undang-undang No. I0 tahun 1998 tentang perubahan atas Undang-undang N0.7 tahun I992 tentang Perbankan. Berdasarkan kebijakan tersebut, perkembangan kebijakan perbankan islam di Indonesia dapat diklasifikasikan dalam dua periode, yaitu periode I992-1998 dan periode I998-1999. Pada tahun 1992 menjadi tonggak utama keberadaan Bank Syariah dengan didirikan Bank Muamalat Indonesia, aspek politik, ekonomi dan hukum tidak bisa lepas pada pendirian bank syariah tersebut. ${ }^{3}$ (Aswad 2015) Keberadaan bank syariah merupakan salah satu alat untuk mewujudkan pemberdayaan ekonomi masyarakat dengan tetap menggunakan akad syariah didalam.

Keberadaan bank mini syariah di lembaga pendidikan khsusunya pesantren, bisa mempengaruhi dalam isi kurikulum dan keahlian dibidang keuangan berpotensi menghasilkan lulusan yang unggul dalam bidangnya. Kurikulum dan keahlian dibidang keuangan pada lingkup pesantren masih kurang memadai, belum ada link and match antara industri keuangan dengan pesantren, masalah terbesarnya adalah sosialisasi dan edukasi. Oleh karena permasalahan ini ada kaitannya dengan peran pesantren dalam menghasilkan

\footnotetext{
${ }^{2}$ Abd Halim, Manajemen Pesantren (Pustaka Pesantren, 2005).

${ }_{3}^{3}$ Muhammad Aswad, 'Ekonomi Politik Keuangan Syariah Di Indonesia', Dinamika Penelitian: Media Komunikasi Penelitian Sosial Keagamaan, I5.I (2015), 29-48.
} 
Muh Zainuddin S., dkk.

lulusan yang kompeten, salah satu hal pokok dan penting dalam proses tersebut adalah adanya laboratorium dan lembaga keuangan yang dapat meningkatkan kompetensi lulusan yang sangat baik serta model pemerdayaan bagi pesantren tersebut. Oleh karena itu, pemberdayaan bank mini syariah di pesantren sebagai sarana dalam pendidikan ekonomi pesantren juga dapat menyokong dan memberikan kontribusi akselarasi perkembangan terhadap perkembangan perbankan syariah di Indonesia.

Peluang dan harapan pemberdayaan Bank Mini Syariah disebuah lembaga pesantren tentu berharap dapat menyokong kegiatan pengelolaan keuangan lembaga pendidikan dan mampu meningkatkan kompetensi keahlian melalui praktek-praktek laboratoriuum keuangan (bank mini), dan tentunya berpeluang besar bagi lembaga terdidik untuk mengasah ilmu yang didapat dalam bangku formal.

Berdasarkan uraian diatas, pengembangan Bank Mini Syariah di Pesantren Nurul Jadid menarik untuk dilakukan penelitian, hal ini dikarenakan pesantren nurul jadid tidak hanya berkembangan dari sisi pendidikan, namun juga bisa berkembang dari sisi ekonomi, dari perubahan transaksi dan bisa menjadi laboratorium bagi seluruh santri yang memiliki kompetensi pada transaksi keuangan syariah.

Sebuah lembaga pesantren, bukan hanya menjadi lembaga transformasi pendidikan, namun juga harus bisa menjadi lembaga pemberdayaan masyarakat dari segala sisi, salah satunya pada aspek ekonomi dan keuangan. Entitas pesantren sebagai lembaga pendidikan Islam, harus memiliki peran dalam pengembangan ekonomi syariah ataupun transaksi ekonomi syariah lainnya. Sehingga pesantren harus untuk mewujudkan cita-cita tersebut diatas dengan memiliki lembaga keuangan yang menjadi cikal bakal sebuah lembaga keuangan syariah besar, dalam hal ini dikenal sebagai Bank Mini Syariah, dengan lembaga tersebut, diharapkan bisa menjadi kontribusi terhadap perkembangan bank syariah secara umum ataupun transaksi ekonomi di pesantren secara khusus.

Realita perkembangan bank syariah di Indonesia, sebagai lembaga keuangan syariah mengalami peningkatan, hal ini dibuktikan dengan peningkatan jumlah lembaga keuangan

Volume. 9/No. 2/Juli 202I Al-Iqtishod|2I 
Bank Mini Syariah di Pesantren ...

yang memakai model syariah. Data Otoritas Jasa Keuangan (OJK) mencatat I3 Bank Umum Syariah yang telah beroperasi di Indonesia. Hal ini menunjukkan prospek yang bagus dalam pengembangan Bank Syariah dalam lingkup internal di Nurul Jadid, sehingga bisa mendirikan dengan istilah Bank Mini Syariah. Dalam penelitian ini akan di mulai melalui data yang bisa mendukung berdirinya Bank Mini Syariah di Nurul Jadid, analisis SWOT akan dipakai untuk menjawab peluang dan harapan tersebut. Diharapkan nanti, hasil penelitian ini bisa menjadi dasar serta pertimbangan dalam pengembangan lembaga keuangan syariah dan Bank Mini Syariah di Nurul Jadid.

\section{B. Kajian Pustaka}

Bank merupakan lembaga keuangan yang melayani penyimpangan dan penyaluran dana kepada masyarakat yang menggunakan jasa bank sebagai tempat melaksanakan transaksi keuangannya. Pada dasarnya bank memiliki peran dua sisi, yaitu menghimpun dana secara langsung (yang berasal dari masyarakat yang kelebihan dana (suplus unit)) dan menyalurkan dana kepada masyarakat secara langsung yang membutuhkan dana (defisit unit) untuk memenuhi kebutuhannya, sehingga bank di sebut dengan financial depository institution. $^{4}$

Menurut Undang-undang Nomor I0 Tahun 1998 tentang Perbankan "Bank adalah badan usaha yang menghimpun dana dari masyarakat dalam bentuk simpanan dan menyalurkannya ke masyarakat dalam bentuk kredit dan atau bentuk lainnya dalam rangka meningkatkan taraf hidup rakyat banyak.”

Sedangkan pengertian Syariah secara harfiah ialah jalan yang di tempuh atau garis yang di tempuh atau garis yang mesti di lalui. Secara terminologi syariah adalah Peraturan peraturan dan hukum yang telah di gariskan oleh Allah atau telah di gariskan pokok pokoknya dan di bebankan kepada umat Islam untuk mematuhi dan melaksanakannya, hal ini bertujuan agar syariah dijadikan penghubung diantaranya dengan Allah dan dengan

${ }^{4}$ M B A Ismail, Perbankan Syariah (Kencana, 2017).

22| A1-Iqtishod Volume. 9/No.2/Juli 202I 
Muh Zainuddin S., dkk.

manusia yang lain. ${ }^{5}$ Secara garis besar, syariah berisi peraturan dan hukum-hukum yang menentukan segala aktifitas hidup umat islam.

Sehingga jika digabungkan, maka pengertian Bank Syariah adalah sebuah usaha bidang perbankan yang berguna sebagai penghimpun dana dan penyalur dana kepada masyarakat yang mana hukum dan sistemnya sesuai dengan hukum islam seperti mengikuti tata cara berusaha dan perjanjian berusaha yang di tentukan dalam al-Quran dan hadist. Pada zaman nabi Muhammad saw, Bank Syariah secara kelembagaan belum ditemukan, namun prinsip yang dilaksanakan pada praktek perbankan syariah telah dilaksanakan pada zaman nabi Muhammad tersebut, karena pada zama tersebut, perdagangan telah menjadi urat nadi perekonomian di jazirah arab.

Menurut beberapa literatur, bank syariah dijelaskan sebagai sebuah lembaga keuangan bank, yang memakai prinsip dalam Islam, baik dari transaksi maupun operasionalnya. Definisi lain menyebutkan Bank syariah merupakan lembaga keuangan bank yang memberikan pembiayaan dan jasa keuangan lainnya menggunakan prinsip syariah sesuai fiqh kontemporer. ${ }^{6}$

Pada prosesnya Bank syariah merupakan sebuah lembaga intermediasi dan penyedia jasa keuangan yang bekerja berdasarkan etika dan sistem nilai islam. Berkembangnya bankbank syariah di Negara-negara Islam berpengaruh ke Indonesia, pada awal periode I980an, diskusi mengenai bank syariah sebagai pilar ekonomi islam mulai dilakukan, hal ini untuk menengahi sistem ekonomi kapitalis dan sosialis. Para tokoh yang terlibat dalam kajian tersebut adalah Karnaen A. Perwataatmadja, M. Dawam Rahardjo, A.M. Saefuddin, M. Amien Aziz, dan lain-lain. ${ }^{7}$

Bank islam di Indonesia pertama kali adalah bank Muamalat Indonesia yang diresmikan pada tanggal I November I99I, dan resmi dibuka pada tanggal I Mei 1992 dengan modal awal Rp 106.382.000,00. Kemudian bank syaiah ke dua di Indonesia adalah Bank Syariah Mandiri (BSM), bank syariah mandiri secara struktur berasal dari

\footnotetext{
${ }^{5}$ Adiwarman A Karim, 'Bank Islam: Analisis Fiqih Dan Keuangan Ed 5', 2017.

${ }^{6} \mathrm{~S}$ E Andrianto, M Ak, and M Anang Firmansyah, Manajemen Bank Syariah (Penerbit Qiara Media, 2019).

${ }^{7}$ M Amin Aziz, 'Mengembangkan Bank Islam Di Indonesia', Bankit, Jakarta, 1993.
}

Volume. 9/No. 2/Juli 202I A1-Iqtishod|23 
Bank Mini Syariah di Pesantren ...

bank sulisa bakti (BSB), bank susila bakti dibeli oleh perusahaan dagang Negara, kemudian dikonversikan menjadi Bank Syariah Mandiri secara penuh. Perkembangan lain perbankan Syariah di Indonesia pasca era reformasi adalah berkembanganya konversi cabang bank umum konvensional menjadi cabang syariah. ${ }^{8}$

Prinsip dasar yang harus selalu dipegang teguh oleh setiap bank syariah, dalam prosesnya harus mengikuti unsur kesesuaian dengan legalitas operasionalnya sesuai dengan hukum di Indonesia serta unsur kesesuaian dengan prinsip syariah. Sedangkan prinsip dasar perbankan syariah adalah; harus menghindari terhadap transaksi uang atau barang yang mengandung keharaman dan harus menghindari transaksi yang sistemnya menyalahi prinsip syariah. Sehingga pada bank syariah tidak bisa dilepas dari Dewan Pengawas Syariah (DPS) untuk memastikan bahwa transaksi yang dilakukan telah sesuai dengan prinsip syariah.

I. Transaksi keuangan pada Bank Syariah

Dalam setiap transaksi syariah, seperti transaksi jual beli atau sejenisnya dan muamalah yang lain, baik antara orang perorangan atau lebih, perorangan dengan lembaga atau antar lembaga dalam hal apapun harus berdasarkan akad (jalinan ikatan). Akad atau perjanjian mengatur hubungan keterikatan antara para pihak mengenai hak dan kewajiban yang memuat tentang identitas pihak pihak terkait dan isi perjanjian. Apabila kedua belah pihak telah melakukan perjanjian maka telah sah memiliki status yang memikat dalam suatu perjanjian dan akan mendapat sanksi bila ternyata terjadi hal hal yang di luar kemampuan atau adanya dugaan pelanggaran atas akad.

Salah satu transaksi dalam perbankan syariah dalam bidang Penggalangan dana (funding) terdapat beberapa bagian :

a. Wadi'ah, dalam prinsip fiqih dikenal dengan akad titipan atau simpanan. Wadi'ah dapat diartikan sebagai titipan murni dari satu pihak ke pihak lain, baik individu maupun badan hukum, yang harus dijaga dan dikembalikan kapan saja, jika yang

${ }^{8}$ Muhammad Syafi'i Antonio, 'Bank Syariah Bagi Bankir \& Praktisi Keuangan', Jakarta: Tazkia Institue, 1999. 
Muh Zainuddin S., dkk.

menitipkan menghendaki untuk diambil kembali. ${ }^{9}$ Tentunya, pihak bank dalam hal ini akan mendapatkan bagi hasil dari pengguna dana titipan tersebut, pengelola bank bisa memberikan insentif kepada orang yang menitipkan dalam bentuk bonus atau bagi hasil.

b. Musyarakah merupakan akad kerja sama antara dua pihak atau lebih untuk suatu tujuan tertentu, dimana masing-masing pihak memberikan kontribusi dana dengan kesepakatan tertentu atau bahwa keuntungan dan risiko akan ditanggung bersama sesuai dengan kesepakatan. ${ }^{10}$

c. Mudharabah merupakan akad kerja sama dalam bidang usaha antara dua pihak; dimana pihak pertama (shahibul maal) menyediakan seluruh modal, sedangkan pihak lainnya menjadi pengelola. Keuntungan usaha dibagi menurut kesepakatan yang dituangkan dalam kontrak, sedangkan apabila rugi ditanggung oleh pemilik modal selama kerugian itu bukan akibat kelalaian si pengelola. Seandainya kerugian itu diakibatkan karena kecurangan atau kelalaian pengelola, maka pengelola harus bertanggung jawab atas kerugian tersebut. ${ }^{11}$

d. Juali beli Salam adalah sebuah akad pembelian, yang barang diperjualbelikan tersebut diserahkan dikemudian hari, sedangkan pembayaran dilakukan dimuka.

e. Jual beli Istishna' adalah kontrak penjualan anatara pembeli dan pembuat barang. Dalam kontrak ini, pembuat barang menerima pesanan dari pembeli. Pembuat barang lalu berusaha melalui orang lain untuk membuat atau membeli barang menurut spesifikasi yang telah disepakati dan menjualnya kepada pembeli akhir. Kedua belah pihak bersepakat atas harga serta sistem pembayaran: apakah pembayaran dilakukan dimuka, melalui cicilan, atau ditanggunhkan sampai suatu waktu pada masa yang akan datang.

${ }^{9}$ Sayyid Sabiq, 'Fiqh Sunnah, Terj', Semarang: Toha Putra, 1972.

${ }^{10}$ M Pudjiraharjo and Nur Faizin Muhith, Fikih Muamalah Ekonomi Syariah (Universitas Brawijaya Press, 2019).

${ }^{11}$ Sabiq.

Volume. 9/No. 2/Juli 202I A1-Iqtishod|25 
Bank Mini Syariah di Pesantren ...

f. Ijarah adalah akad pemindahan hak guna atas barang atau jasa, melalui pembayaran upah sewa, tanpa diikuti dengan pemindahah kepemilikan (ownership/milkyyah) atas barang itu sendiri. ${ }^{12}$

Transaksi dalam perbankan syariah juga melayani Penyaluran dana (pembiayaan), yakni:

a. Wakalah secara harfiyah diartikan dengan penyerahan, pendelegasian, atau pemberian mandat. Dalam kalimat Arab, hal ini dapat dipahami sebagai attafwidh. Pada transaksi bank syariah dijelaskan bahwa wakalah merupakan akad untuk melaksanakan perwakilan, yang mana nasabah memberikan perwakilan untuk melakukan sebuah transaksi kepada Bank, dengan tanda jasa yang telah ditentukan diawal akad. Secara ringkas Wakalah merupakan pelimpahan kekuasaan oleh nasbaha kepada bank dalam hal-hal yang diwakilkan.

b. Kafalah adalah akad jaminan yang diberikan oleh penanggung (kafiil) kepada pihak ketiga untuk memenuhi kewajiban pihak kedua atau yang ditanggung (makfuul 'anhu, ashil). Dalam produk perbankan kafalah dipakai untuk LC, Bank guarantee dll.

c. Hiwalah ialah akad pengalihan hutang dari satu pihak yang berhutang kepada pihak lain untuk menanggung (membayar)-nya. Dalam industri perbankan hiwalah dengan upah (fee, ujroh) dipergunakan untuk pengalihan utang dan bisa juga untuk LC.

d. Rahn (gadai) yaitu adalah menyimpan sementara harta milik peminjam sebagai jaminan atas pinjaman yang diberikan oleh pemberi hutang, perbedaan gadai syariah dengan konvensional adalah mengenai bunga dari pinjaman tersebut. Gadai Syariah menerapkan beberapa sistem pembiayaan, antara lain qardhun hasan (pinjaman kebajikan), mudharobah (bagi hasil) dan muqayyadah (jual beli). ${ }^{13}$

${ }^{12}$ S H Sutan Remy Sjahdeini, Perbankan Syariah: Produk-Produk Dan Aspek-Aspek Hukumnya (Kencana, 2018).

${ }^{13}$ Sutan Remy Sjahdeini. 
Muh Zainuddin S., dkk.

2. Perbedaan Bank Syariah dan Bank Umum

Dalam beberapa sisi, memang bank syariah dan bank konvensional mempunyai persamaan, tentu juga mempunyai perbedaan, karena dalam bank syariah itu sendiri akad yang dilakukan memiliki konsekuensi duniawi dan ukhrawi berdasarkan hukum Islam. Seringkali nasabah berani melanggar kesepakatan/perjanjian yang telah dilakukan bila hukum itu hanya berdasarkan hukum positif saja, tapi tidak demikian bila perjanjian tersebut memiliki petanggungjawaban secara ukhrawj, karena berhubungan dengan keyakinan diri setiap umat Islam

Perbedaan antara bank syariah dan bank konvensional, sebagai berikut :

\begin{tabular}{|c|c|c|}
\hline & $\begin{array}{c}\text { BANK } \\
\text { KONVENSIONAL }\end{array}$ & BANK SYARIAH \\
\hline $\begin{array}{l}\text { Fungsi dan kegiatan } \\
\text { bank mekanisme dan } \\
\text { objek usaha }\end{array}$ & $\begin{array}{l}\text { Intermediasi, } \quad \text { jasa } \\
\text { keuangan }\end{array}$ & $\begin{array}{l}\text { Intermediasi, manager, } \\
\text { investasi. Investor, sosoal, } \\
\text { jasa keuangan }\end{array}$ \\
\hline Prioritas keuangan & $\begin{array}{l}\text { - Bebas nilai (prinsip } \\
\text { materialisme) } \\
\text { - Unang sebagai komiditi } \\
\text { - Bunga }\end{array}$ & $\begin{array}{l}\text { - Tidak bebas nilai } \\
\text { prinsip syariah islam. } \\
\text { - Uang sebagai alat tukar } \\
\text { bukan komoditi } \\
\text { - Bagi hasil, jual beli, sewa }\end{array}$ \\
\hline Orientasi & Kepentingan pribadi & Kepentingan public \\
\hline Bentuk & Keuntungan & $\begin{array}{l}\text { Tujuan sosial-ekonomi } \\
\text { islam, keuntungan }\end{array}$ \\
\hline Evaluasi nasabah & Bank komersial & $\begin{array}{l}\text { Bank komersial, bank } \\
\text { pembangunan, bank } \\
\text { universal multi-purpose }\end{array}$ \\
\hline Hubungan nasabah & $\begin{array}{l}\text { Kepastian pengembalan } \\
\text { pokok dan bunga }\end{array}$ & $\begin{array}{l}\text { Lebih hati-hati karena } \\
\text { partisipasi dalam resiko }\end{array}$ \\
\hline $\begin{array}{l}\text { Sumber likuiditas } \\
\text { jangka pendek }\end{array}$ & Terbatas debitor-kreditor & Erat sebagai mitra usaha \\
\hline $\begin{array}{l}\text { Pinjaman } \\
\text { diberikan }\end{array} \quad$ yang & Pasar uang, bank sentral & Terbatas \\
\hline $\begin{array}{l}\text { Lembaga penyelesaian } \\
\text { sengketa }\end{array}$ & 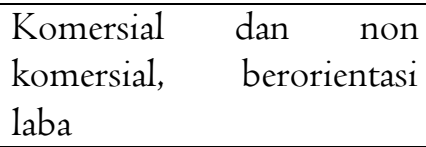 & $\begin{array}{l}\text { Komersial dan noon } \\
\text { komersial, beroriantasi laba } \\
\text { dan nirlaba }\end{array}$ \\
\hline Risiko usaha & Pengadilan, arbitrase & $\begin{array}{l}\text { Pengadilan, badan arbitrase } \\
\text { syariah nasional }\end{array}$ \\
\hline
\end{tabular}

Volume. 9/No. 2/Juli 202I A1-Iqtishod|27 
Bank Mini Syariah di Pesantren ...

\begin{tabular}{|l|l|l|}
\hline $\begin{array}{l}\text { Struktur organisasi } \\
\text { pengawas }\end{array}$ & $\begin{array}{l}\text { - Resiko bank tidak } \\
\text { terkait langsung dengan } \\
\text { debitor, resiko debitor } \\
\text { tidak terkai langsung } \\
\text { dengan bank } \\
\text { - Kemungkinan terjadi } \\
\text { negative spread }\end{array}$ & $\begin{array}{l}\text { Dihadapi bersama } \\
\text { anatara bank dan } \\
\text { nasabah dengan prinsip } \\
\text { keadilan dan kejujuran } \\
\text { Tidak mungkin terjadi } \\
\text { negative spread }\end{array}$ \\
\hline Investasi & Dewan komisaris & $\begin{array}{l}\text { Dewan komisaris, dewan } \\
\text { pengawas syariah, dewan } \\
\text { syariah nasional }\end{array}$ \\
\hline Status transaksi & Halal atau haram & Halal \\
\hline
\end{tabular}

3. Kelebihan dan kekurangan Bank Syariah

Perkembangan Bank Syariah tidak lepas dari kekurangan dan kelebihan, karena setiap nasabah perbankan memiliki persepsi yang berbeda tentang status perbankan tersebut. Kelebihan Bank Syariah antara lain;

a. Ikatan emosional keagamaan antara pemegang saham, pengelola bank, dan sabahnya sangat kuat. Dari ikatan inilah kebersamaan dalam menghadapi risiko usaha dan membagi keuntungan secara adil dan jujur.

b. Sistem dan pengelolaan pada Bank syariah mendasarkan pada al-Qur'an, Hadist, dan aspek syariah. Sehingga semua pihak yang terlibat dalam bank berpegang teguh dengan ajaran agama sehingga berapapun hasil yang diperoleh diyakini membawa berkah.

c. Adanya pembiayaan mudharobah dan musyarokah yang tidak membebani nasabah sejak awal dengan kewajiban membayar biaya secara tetap. Tentu hal ini memberikan kelonggaran psikologis yang diperlukan nasabah untuk dapat berusaha secara tenang dan sungguh-sungguh.

d. Penerapan sistem bagi hasil dan ditinggalkannya sistem bunga menjadikan Bank syariah lebih berpengaruh pada gejolak moneter baik dari dalam maupun luar negeri.

28| Al-Iqtishod Volume. 9/No.2/Juli 202I 
Muh Zainuddin S., dkk.

Selain sisi kelebihan bank syariah yang sangat dominan terhadap konsep syariah didalamnya, namun tetap ada kelemahaan yang ada pada Bank Syariah, antara lain;

a. Promosi bank syariah dan produk syariah kurang menyeluruh ke berbagai masyarakat, sehingga masyarakat masih terbiasa dengan transaksi perbankan konvensional ataupun sistem rentenir di tengah masyarakat.

b. Kemajuan teknologi yang sangat pesat, belum dijawab dengan serius oleh pengelola perbankan, sehingga nasabah masih lebih bank konvensional

c. Pelayanan bank syariah masih jauh dari domisili masyarakat, karena posisi kantor bank syariah masih di kota/kabupaten, belum ke kecamatan atau pelosok sekalipun

d. Fasilitas penunjang dalam transaksi, masih minim, sehingga nasabah akan berhitung kembali untuk melakukan transaksi pada bank syariah.

\section{Metode Penelitian}

Penelitian ini merupakan penelitian lapangan (field research) untuk mendapatkan jawaban bagaimana prospek bank mini syariah di lingkungan pesantren Nurul Jadid, dalam analisinya menggunakan metode SWOT (Strengths (Kekuatan), Weaknesses (Kelemahan), Opportunities (Peluang), dan Threats (Ancaman)). Analisis SWOT merupakan sebuah metode analisis perencanaan untuk merencanakan dan melakukan evaluasi lingkungan eksternal dan internal untuk suatu kepentingan tertentu, dalam hal ini digunakan untuk menjawab bagaimana prospek Pesantren Nurul Jadid dalam pendirian dan pengelolaan Bank Mini Syariah.

\section{Hasil dan Pembahasan}

\section{Profil Pesantren Nurul Jadid Paiton Probolinggo}

Keberadaan PP Nurul Jadid tak lepas dari konstruksi kemasyarakatan yang mencitakan suatu transendensi atas perjalanan historisitas sosial. Hal yang menjadi titik penting adalah kenyataan eksistensi pesantren sebagai salah satu pemicu 
Bank Mini Syariah di Pesantren ...

terwujudnya kohesi sosial. Keniscayaan ini karena pesantren hadir terbuka dengan semangat kesederhanaan, kekeluargaan dan kepedulian sosial.

Berdirinya Pondok Pesantren Nurul Jadid memang bukan sekedar untuk pemenuhan kebutuhan keilmuan, melainkan juga penjagaan budaya, penyebaran etika dan moralitas keagamaan. Tak heran, pada periode awal ini santri lebih diarahkan agar lebih memahami bentuk aplikasi dari teori ilmu-ilmu keagamaan yang mereka pelajari dalam kitab-kitab kuning. Sehingga nantinya, para santri bisa mengamalkan teori ilmu-ilmu keagamaan secara tepat dan benar ketika sudah terjun di tengah-tengah masyarakat. Bentuk aplikasi ilmu keagamaan tersebut dilakukan dalam bentuk pendampingan kepada masyarakat.

Hal itu bisa dilihat misalnya dalam bidang ekonomi, khususnya pertanian. Sektor ekonomi ini dijadikan prioritas. Hal ini tidak lepas dari pendapat beliau bahwa jika bidang perekonomian suatu masyarakat lemah, maka acapkali hal itu menjadi salah satu pemicu tumbuh-berkembangnya perilaku amoral dan kufur. Pendapat itu beliau utarakan setelah beliau melakukan analisa terhadap situasi dan kondisi perekonomian masyarakatnya amat rendah. Selain itu, Karanganyar juga terkenal sebagai pusatnya bromocorah. Namun, tanah di Karanganyar sebanarnya merupakan kategori tanah yang cukup produktif. Hanya saja, masyarakatnya belum bisa memanfaatkannnya dengan baik.

Setelah perekonomian masyarakat mulai meningkat melalui pemanfaatan tanah pertanian, mulailah dimasukkan ajaran dan nilai-nilai agama islam dalam kehidupan masyarakat Karanganyar. Hal lainnya adalah pendalaman ilmu agama melalui sistem pendidikan non formal. Pola pendidikan dan pembinaan semacam itu dilakukan, baik kepada santri maupun kepada masyarakat sekitar pesantren. Pengajian kitab dilakukan dengan berbagai metode. Mulai dari bandongan, sorogan dan takhassus. Sementara itu pemberian makna dalam pengajian kitab kuning menggunakan bahasa indonesia. Sehingga pesantren Nurul Jadid 
Muh Zainuddin S., dkk.

merupakan pesantren pertama yang menggunakan bahasa Indonesia dalam menerangkan dan menterjemahkan kitab-kitab yang dikajinya.

Pada aspek pengembangan ekonomi, PP Nurul Jadid telah melakukan berbagai kegiatan dan pendirian lembaga, salah satunya Gerai Muamalah Nurul Jadid, yang merupakan lembaga keuangan syariah yang mengikuti prosedur Bank Muamalah, pada fungsinya Gerai Muamalah Nurul Jadid merupakan perbankan syariah Mikro (mikro finance). Lembaga ini bergerak pada layanan transaksi keuangan baik pengumpulan dana dan pinjaman dana. Namun dalam perjalanannya tidak begitu mulus, terdapat berbagai kendala, sehingga kisaran tahun 20I7, sudah tidak melayani.

\section{Analisis Swot}

Prospek suatu lembaga keuangan, khususnya Perbankan Syariah secara relatif dapat dilihat dari metode analisis yang digunakan untuk mengevaluasi kondisi lembaga tersebut, salah satu metode yang dikenal adalah SWOT (Strengths (Kekuatan), Weaknesses (Kelemahan), Opportunities (Peluang), dan Threats (Ancaman)), sehingga prospek dan kondisi Perbankan Syariah di Indonesia dapat diketahui dan dijadikan dasar untuk pengembangan. ${ }^{14}$ Dengan meneliti kekuatan, kelemahan, peluang, dan tantangan dalam Perbankan Syariah.

Analisis SWOT ini pada prakteknya merupakan cara untuk menganalisis dan menginventarisir berbagai hal yang mempengaruhi kondisi perbankan syariah. Sehingga dari sisi kekuatan (strength) bisa mendapatkan keuntungan dari peluang (opportunitites) yang dimiliki oleh bank syariah tersebut. Selain itu, dari sisi kelemahan (weaknes) yang terdapat pada Bank Syariah bisa diatasi melalui peluang (opportunitites) yang dimiliki. Kekuatan (strength) dari bank syariah harus bisa menjawab dan menghadapi ancaman (threats) yang mengancam kondisi bank

\footnotetext{
${ }^{14}$ Nur Rianto, 'Pengantar Ekonomi Syariah', Teori Dan Praktik, Pustaka Setia, Bandung, 2015.
}

Volume. 9/No. 2/Juli 202I A1-Iqtishod|3I 
Bank Mini Syariah di Pesantren ...

syariah. Terakhir merupakan cara untuk mengatasi kelemahan (weaknes) yang bisa menjadi ancaman (threats) terhadap keberlangsungan bank syariah. ${ }^{15}$

a. Kekuatan (strength)

Perbankan syariah memiliki karakteristik khas yang menjadi unggulan dibandingkan dengan bank konvensional. Keunggulan-keunggulan pada bank syariah menjadi nilai lebih, menjadi kekuatan yang mampu menggerakkan Perbankan Syariah di Indonesia untuk berkembang kearah lebih baik dalam rangka memperluas pemasaran Bank Syariah dan produk Bank Syariah.

- Mayoritas penduduk Indonesia merupakan umat Islam, sehingga hal ini menjadi senjata utama berkembangnya Bank Syariah

- Lembaga keuangan mendukung hadirnya transaksi keuangan yang memakai prinsip syariah dalam lingkup bank syariah.

- Prinsip pada transaksi keuangan telah sesuai dengan syariah Islam, dan dipahami oleh seluruh umat Islam

- Pengelola bank syariah mendorong kebersamaan dengan nasabah untuk samasama menghadapi resiko usaha, keuntungan, dan ataupun kerugian secara adil.

- Bank syariah memiliki produk pinjaman murah yang lebih dikenal sebagai akad Qardh hasan, yang selanjutnya dikelola pada Baitul Maal. ${ }^{16}$

- Pelaksanaan prinsip syariah pada bank syariah diawasi secara ketat oleh Dewan Pengawas Syariah yang telah tersertifikasi oleh MUI.

b. Kelemahan (weaknes)

Selaian mempunyai kekuatan yang menjadi nilai tambah bagi perbankan Syariah juga memiliki kelemahan dan kendalan yang dihadapi oleh perbankan syariah di Indonesia.

${ }^{15}$ Eva Fauziah, Ifa Hanifia Senjiati, and Sandy Rizki Febriadi, 'Model Pemberdayaan Laboratorium Bank Mini Syariah Di Perguruan Tinggi, Muqtasid: Jurnal Ekonomi Dan Perbankan Syariah, 8.2 (2017), I02I8.

${ }^{16}$ Amirus Sodiq, 'ANALISIS SWOT PERKEMBANGAN PERBANKAN SYARIAHDI INDONESIA', MALIA: Journal of Islamic Banking and Finance, I.I (2018).

32| Al-Iqtishod Volume. 9/No.2/Juli 202I 
- Persepsi masyarakat terhadap bank, riba, sistem akuntansi, perhitungan bagi hasil, profit, loss sharing, dan margin harga jual pada akad transaksi di bank syariah.

- Tenaga ahli pada bidang bank syariah masih minim, sehingga pada prosesnya, harus ada pengawas eksternal untuk menjamin proses transaksinya

- Rendahnya pemahaman masyarakat tentang kondisi bank syariah

- Jaringan pelayanan bank syariah masih terbatas dan berpusat pada wilayah kota saja

- Keberhasilan sistem bagi hasil pada pembiayaan mudharabah dan musyarakah masih ngambang dan tergantung pada nasabah.

c. Peluang (opportunitites)

- Pada proses perkembangan bank syariah bisa menggandeng lembaga pendidikan maupun lembaga keagamaan sebagai corong untuk mempromosikan transaksi dan sistem operasional bank syariah, atau bahkan mendirikan lembaga keuangan yang mirip dengan bank syariah tersebut.

- Anggapan umat Islam, bahwa transaksi keuangan yang ada bunga, paja, dan riba, jelas keharamannya

- Pada sejarahnya, bank syariah lebih tahan pada krisis moneter tahun 1997 yang pada kemudian hari berkembangan menjadi krisis ekonomi. Karena bank syariah tidak tergantung pada dolar amerika. ${ }^{17}$

- Konsep transaksi pada bank syariah, hitungannya lebih menguntungkan pada produksi perdagangan serta kebersamaan pada investasi.

- Upaya pemurnian syariah pada setiap lini kehidupan masyarakat.

d. Tantangan (threat)

- Tantangan terbesar pada posisi bank syariah adalah kaitan dengan fanatisme beragam umat Islam saat ini, sehingga orang-orang yang merasa terganggu

${ }^{17}$ Sodiq.

Volume. 9/No. 2/Juli 202I A1-Iqtishod|33 
Bank Mini Syariah di Pesantren ...

dengan fanatisme tersebut akan menyerang balik terhadap perkembangan bank syariah

- Potensi pemilikan bank syariah oleh asing

- Kualitas daya manusia yang belum merata

- Permodalan yang belum ketat

- Kemerosotan keyakinan umat Islam, karena lebih tergoda pada aspek materi.

\section{Prospek Bank Mini Syariah di Pesantren Nurul Jadid}

Lembaga pendidikan, khususnya pesantren harus turut andil dalam pengembangan ekonomi masyarakat, tidak hanya dalam pengembangan pendidikan saja. Pendampingan terhadap masyarakat sangat dibutuhkan, terlebih menyangkut keberlangsungan hidup mereka. Pada bagian ini, pesantren harus hadir untuk bisa menjadi sarana pengembangan ekonomi masyarakat sekitar pesantren. Banyak cara yang bisa dipakai untuk pengembangan ekonomi pada lingkup lembaga pendidikan, bisa dengan koperasi, BMT, atau bekerjasama dengan sebuah perbankan untuk mendirikan mini bank dalam lingkup lembaga pendidikan tersebut.

Pada beberapa perguruan tinggi dan sekolah menengah kejuruan telah bekerjasama dengan lembaga perbankan untuk mendirikan mini bank, sebagai cabang kecil di lembaga pendidikan untuk melayani masyarakat serta wahana edukasi bagi peserta didik di lembaga tersebut. Sebagai contoh Bank Mini Syariah yang telah berdiri di UIN Sunan Ampel Surabaya, yang dalam pendiriannya bekerjasama dengan BPRS Untung Suropati Pasuruan. Sehingga bank mini dalam operasionalnya tetap mengacu pada proses pelayanan lembaga perbankan secara umum.

Bank Mini Syariah secara fungsi merupakan tempat melakukan kegiatan transaksi keuangan yang diselenggaran oleh lembaga pendidikan baik itu SMK, perguruan tinggi, maupun pesantren itu sendiri, hal ini untuk meningkatkan kompetensi peserta didik pada bidang perbankan syariah yang memadukan 
Muh Zainuddin S., dkk.

pengetahuan dan praktis dalam suatu kegiatan bank syariah yang terintegrasi. Dalam operasionalnya Bank Mini Syariah bisa melayani masyarakat apabila sudah mendapatkan izin operasional dari OJK, dan dalam perjalasanannya tentu berpengaruh pada perkembankan Bank Syariah di Indonesia. Posisi bank mini syariah merupakan bentuk aplikatif dari teori yang telah dipekajari oleh peserta didik.

Bank mini syariah tidak hanya sebagai lembaga transaksi keuangan syariah, juga menjadi laboratorium bagi peserta didik yang memiliki kompetensi dalam transaksi keungan. Dalam proses di bank mini syariah tetap menyerupai pelayanan di bank syariah secara umumnya, serta tujuan utama menjadi tempat belajar bagi seluruh peserta didik di lokasi bank mini syariah tersebut. bank mini syariah juga dapat diberdayakan menjadi laboratorium untuk melakukan transaksi riil. Artinya, laboratorium tersebut bisa menjadi tempat transaksi riil baik dalam penghimpunan dana maupun dalam penyaluran dana namun terbatas pada civitas akademika atau dapat pula diperluas cakupan kerjanya ke masyarakat luar kampus apabila sudah mendapat izin operasional dari pihak OJK, yang kemudian dapat menjadi unit usaha dari Laboratorium/Prodi/Fakultas yang bersangkutan serta dapat pula bekerja sama dengan lembaga keuangan lain di luar kampus.(Fauziah, Senjiati, and Febriadi 2017)

Pesantren Nurul Jadid sebagai salah satu pesantren yang cukup diperhitungkan di wilayah Kab. Probolinggo, bisa mengambil peran didalamnya untuk pengembangan ekonomi dalam bidanh lembaga keuangan syariah. Pesantren Nurul Jadid telah bekerjasama dengan dengan beberapa perbankan, diantaranya Bank Jatim, BNI 46, BNI Syariah, BRI, Mandiri.

Dengan kekuatan tersebut, Pesantren Nurul Jadid sangat berpeluang untuk mendirikan Bank Mini Syariah sebagai layanan ekonomi masyarakat pesantren serta menjadi laboratorium bagi berbagai jurusan yang berhubungan dengan keuangan, selain itu pesantren memiliki kekuatan aset keuangan dari masyarakat 
Bank Mini Syariah di Pesantren ...

pesantren yang dikemudian hari menjadi nasabah. Sisi lainnya, Bank mini syariah di pesnatren Nurul Jadid memiliki kelemahan dari sisi tenaga ahli yang akan mengelola bank mini syariah tersebut, serta pada sisi pelayanan terhadap masyarakat.

Sisi eksternal pengembangan bank mini syariah di Pesantren Nurul Jadid memiliki peluang pengelolaan dana yang besar dari masyarakat pesantren sendiri, dengan mewajibkan seluruh dosen, guru, karyawan, dan bahkan wali santri menjadi nasabah pada bank mini syariah tersebut, bank yang telah bekerjasama pastinya akan membuka pintu lebar jika Pesantren Nurul Jadid hendak bekerjasama untuk pendirian bank mini syariah di dalam areal pesantren, karena pastinya akan menjadi pelayanan tambahan bagi bank tersebut. Tantangan yang dihadapi adalah maind set masyarakat terhadap lembaga keuangan pesantren nurul jadid sebelumnya, yakni Gerai Muamalat, yang akhirnya tidak melayani, tentunya hal tersebut menjadi tantangan tersendiri ketika akan mendirikan kembali lembaga keuangan berbentuk bank mini syariah, serta adanya beberapa BMT yang lokasi tidak begitu jauh dari area pesantren.

Secara garis besar, Pesantren Nurul Jadid memiliki peluang dan kekuatan yang sangat besar dalam mendirikan Bank Mini Syariah, sehingga akan menjadi tempat perkembangan ekonomi masyarakat pesantren serta menjadi laboratorium keilmuan bagi siswa di dalam Pesantren Nurul Jadid. Tentunya harus dibarengi dengan kesungguhan dari pengelola Bank Mini Syariah nantinya, sehingga bisa berkembangan sesuai mestinya.

\section{E. Simpulan}

Pesantren Nurul Jadid sebagai salah satu pesantren yang cukup diperhitungkan di wilayah Kab. Probolinggo, bisa mengambil peran didalamnya untuk pengembangan ekonomi dalam bidanh lembaga keuangan syariah. Pesantren Nurul Jadid telah bekerjasama dengan dengan beberapa perbankan, diantaranya Bank Jatim, BNI 46, BNI Syariah, BRI, Mandiri.

36| A1-Iqtishod Volume. 9/No.2/Juli 202I 
Muh Zainuddin S., dkk.

Dengan kekuatan tersebut, Pesantren Nurul Jadid sangat berpeluang untuk mendirikan Bank Mini Syariah sebagai layanan ekonomi masyarakat pesantren serta menjadi laboratorium bagi berbagai jurusan yang berhubungan dengan keuangan, selain itu pesantren memiliki kekuatan aset keuangan dari masyarakat pesantren yang dikemudian hari menjadi nasabah.

\section{F. Daftar Pustaka}

Amin Aziz, M, 'Mengembangkan Bank Islam Di Indonesia', Bankit, Jakarta, 1993

Andrianto, S E, M Ak, and M Anang Firmansyah, Manajemen Bank Syariah (Penerbit Qiara Media, 2019)

Aswad, Muhammad, 'Ekonomi Politik Keuangan Syariah Di Indonesia', Dinamika Penelitian: Media Komunikasi Penelitian Sosial Keagamaan, I5.I (20I5), 29-48

Fauziah, Eva, Ifa Hanifia Senjiati, and Sandy Rizki Febriadi, 'Model Pemberdayaan Laboratorium Bank Mini Syariah Di Perguruan Tinggi', Muqtasid: Jurnal Ekonomi Dan Perbankan Syariah, 8.2 (2017), I02-18

Halim, Abd, Manajemen Pesantren (Pustaka Pesantren, 2005)

Ismail, M B A, Perbankan Syariah (Kencana, 2017)

Karim, Adiwarman A, 'Bank Islam: Analisis Fiqih Dan Keuangan Ed 5', 2017

Ningsih, Tirta Rahayu, 'Pemberdayaan Ekonomi Pesantren Melalui Pengembangan Sumber Daya Lokal', Lembaran Masyarakat: Jurnal Pengembangan Masyarakat Islam, 3.I (2017), 57-78

Pudjiraharjo, M, and Nur Faizin Muhith, Fikih Muamalah Ekonomi Syariah (Universitas Brawijaya Press, 2019)

Rianto, Nur, 'Pengantar Ekonomi Syariah', Teori Dan Praktik, Pustaka Setia, Bandung, 2015

Sabiq, Sayyid, 'Fiqh Sunnah, Terj', Semarang: Toha Putra, 1972

Sodiq, Amirus, 'ANALISIS SWOT PERKEMBANGAN PERBANKAN SYARIAHDI INDONESIA', MALIA: Journal of Islamic Banking and Finance, I.I (2018)

Volume. 9/No. 2/Juli 202I A1-Iqtishod|37 
Bank Mini Syariah di Pesantren ...

Sutan Remy Sjahdeini, S H, Perbankan Syariah: Produk-Produk Dan Aspek-Aspek Hukumnya (Kencana, 2018)

Syafïi Antonio, Muhammad, 'Bank Syariah Bagi Bankir \& Praktisi Keuangan', Jakarta: Tazkia Institue, I999 